\title{
Patient Complaints - a Tool for Improving Quality of Nursing Care
}

1 Željka Benceković

1 Vesna Čerfalvi

1 Biserka Režek

1 Natalija Hadžić

${ }^{1}$ Ela Vujanić

${ }^{1}$ University Hospital Centre Sestre milosrdnice, Zagreb, Croatia

Article received: 29.05.2018.

Article accepted: 12.10.2018.

Author for correspodence:

Željka Benceković

Quality Management Department, University Hospital

Centre Sestre milosrdnice

Vinogradska 29, Zagreb, Croatia

E-mail: zeljka.bencekovic@kbcsm.hr

DOI: $10.24141 / 2 / 2 / 2 / 5$

Keywords: complaints, management, nurses, quality

\section{Abstract}

Introduction. Patient complaints are the point of the patient's dissatisfaction with the healthcare service (nursing care, etc.). The inadequate handling of patient complaints may result in negative consequences for the healthcare institutions, but also for employ- ees involved in the healthcare process. Healthcare institutions in the Republic of Croatia are obliged to prescribe procedures for handling complaints of patients who must meet certain criteria. According to these criteria the institutions can introduce their own way of dealing with patient complaints. It includes monitoring, analysis and corrective actions based on the analysis of patient complaints. Nurses make a large number of healthcare staff (especially hospital staff) and they contribute significantly to the overall quality of their services and are an important factor in ensuring quality and positive perception of health care. Therefore, it is important to manage complaints in the field of health care.

Aim. The aim of this paper is to investigate complaints management in the field of nursing care to present a way of handling patient complaints, conduct a patient complaints analysis with special emphasis on complaints related to the work of nurses.

Methods. A database search was conducted to find literature from this area and a retrospective analysis of patient complaints filed through the hospital complaint filing system in the period from 1st January to 31st December 2017.

Results. During this period 147 complaints and 132 commendations were received and analyzed. Of the total number of complaints, 21 (14\%) referred to nurses. Most complaints (66\%) referred to nurses employed in the polyclinic section. They mostly indicated dissatisfaction with communication (40\%) and, in the opinion of patients, inappropriate attitude towards them (31\%).

Conclusion. The results represent guidelines for the implementation of further measures to improve the quality of health care in this area. 


\section{Introduction}

\section{The role of complaints in the healthcare quality system}

Comments and complaints from health service users provide unique pieces of information about their needs and the quality of the health care they receive. Therefore, it is important to pay attention to the needs and the satisfaction of the users and that is the priority of the management of all organizations, as well as the healthcare organizations.

Some authors believe that patient complaints can be a gift which gives valuable feedback from their patients (1). In the healthcare environment they express patient dissatisfaction and may point to problems in providing health services (2). Patient complaints also provide important and additional information on how to improve patient safety, so they are an additional source of data in this area, and are also important for detecting systemic problems in providing health services (3).

Only a small part of people who are dissatisfied will file a complaint (less than 4 percent), but will tell the family and friends about their bad experiences or go to another healthcare facility, if possible (4). This is an argument that requires a proactive approach to getting feedback from health service users, all in order to improve their quality.

When we are considering patient complaints, it should be kept it in mind that they are sometimes individual patient experiences, which also have their own characteristics. They can be emotional and focused on the attitudes and skills of an individual and do not necessarily point to quality healthcare improvement priorities, but usually only point to critical places. In consideration of patient complaints, we should be aware of all the circumstances affecting the healthcare process (such as an overload of staff) which patients are not usually aware of. All of these provide a reason for a serious and systematic approach to patient complaints analysis.

Today there are a lot of $(5,6,7)$ legal regulations and campaigns that are aimed at ensuring and protecting the rights of patients and healthcare workers. In The Republic Croatia the complaints procedure is prescribed in a national legal document (Regulations on standards of healthcare quality and the manner of their application, Official Gazette 79/2011). It includes the criteria that the complaint procedure must contain: a list of contact persons; systematic review and resolution of complaints by the principal or written delegation of this function to a suitable person or commission; the process of referral of the quality of care to the Commission for Internal Control; determining a reasonable time frame for a systematic review and response to the complaint; a complaint decision that must be in writing and sent to the patient. The complaint decision must include the contact person in the health institution, the steps taken in the investigation, the outcome of the complaint process and the end date (6). This is particularly important for hospital healthcare institutions, which must be places where these rights will be emphasized and respected.

Accreditation bodies also require from hospital healthcare institutions to systematically approach patient complaints and describe it as a tool to manage and improve the quality of health care $(8,9)$. Patient complaints may play a significant role in setting quality standards because they require a systematic overview of individual incidents and trigger interventions that will prevent the future problems (10).

In order to address the complaints of the patients, the healthcare institutions create a dialogue with the complainants, investigate complaints and make conclusions for each individual patient (it can be: apologizing, rejection of compensation, etc.) (11). Some institutions develop standardized methods and guidelines for their analysis to describe the type and frequency of phenomena that cause patient complaints (12). The recommendations outlined in the literature on successful complaints management advocate a positive approach to their resolution, ethics, commitment and teamwork.

\section{The role of nurses in the healthcare system}

Nurses, as an important part of the health system, have a significant contribution to achieving the quality of this system. In the Republic of Croatia, they make more than $50 \%$ of healthcare workers, so their services have a significant impact on the quality of the entire system (13). The nursing care is a healthcare service, which implies the importance of quality management of health care as well as cooperation 
with other healthcare practitioners and improving the quality of the entire health system (14).

Due to the presence of nurses and their contribution to the quality of healthcare services, monitoring and analysis of patient complaints in the field of health care is not only an obligation but also a need. In this area, it is useful to follow the complaints management guidelines and consider them in the context of the overall health care provided at a particular institution.

Nurses, along with various affiliated professions, participate in the healthcare process. They operate in accordance with professional standards and legal regulations, and among other things they are obliged to represent patient interests, respect their rights and preserve the reputation of the institution (employer) (15).

Research on healthcare complaints is deficient and unreachable, and the importance of proper access is emphasized in the guidelines issued by professional nursing societies. These recommendations were issued with the aim of assisting nurses in dealing with patient complaints and restoring their confidence in the nursing profession (16).

Handling of patient complaints in the nursing profession is also confirmed by the fact that the International Council of Nurses (ICN) issued guidelines explaining the main aspects of the complaint handling process. It lists the responsibilities in solving incidents and complaints in the case of unacceptable practices and stresses the importance of professionalism for securing public confidence in the nursing profession (25).

\section{Experiences and recommendations for handling complaints}

Today, patient complaints in the healthcare system are increasingly represented. The first article on complaints was published in 1987, and research in this area has since then grown considerably (3). There are numerous reports stating that more than 100,000 complaints per year are reported in the health system that may be related to various dissatisfaction, their consequences and ways of dealing with them $(17,18,19)$.

It is difficult to estimate the number of unsatisfied patients. Written patient complaints that reflect dissatisfaction are just the tip of the iceberg. According to some data, more than one third of the patients in the United States experienced some degree of hospital dissatisfaction, but only a small part of these patients complained (24). There are still a number of barriers to complaints. Some barriers are present in patients (their fears, disrespect...), and some because of an inadequate complaint management system (complicated, unavailable, inconsistent, etc.) (11).

The first systematic English literature review, which included 59 studies and 88,069 omplaints in the healthcare system, suggests a serious and a standardized patient complaints analysis. In conclusion of this systematic review, it is stated that patient complaints can standardize critical sites in clinical, control areas as well as in the area of relationship within the healthcare system (3).

In the research on patient complaints, carried out in the period from 1997 to 2001, in 67 Australian hospitals, differences were compared with regard to the demographic characteristics of patients and the various places where care was provided to patients in hospital healthcare facilities. The categories of complaints related to: communication, availability, health care, patient rights, administrative affairs, hospital environment. The frequency of complaints was $1.42 / 1000$ patients, and they were more frequent in women, people living in cities. Most complaints related to the emergency unit, operating room and polyclinics. Communication was the area where patients most complained and the complaint solution was in most cases satisfactory and without major consequences. The conclusion of this research is to emphasize the standardization and complaint databases (21).

There is very little public talk about problems in the quality system and the complaints of patients on our premises. In a research conducted in 2016 at University Hospital Centre Sestre milosrdnice, the frequency of received and processed patient complaints was 1.08 cases per 10000 treatment cases. The frequency of complaints in this health institution in 2017 was 1.32 cases per 10000 cases of treatment, which is an insignificant increase compared to 2016. The quality of interaction with staff and communication involved $24 \%$ of complaints, patient care and medical records $33 \%$ of complaints, availability of hospital care $31 \%$, infrastructure $6.7 \%$ and hospital accounts 5.3\% (20).

On the other hand, in the more developed healthcare systems more research is being conducted in this 
area, and evidence-based practices are being developed that help health professionals successfully manage patient complaints $(4,22)$.

\section{Managing complaints in the University Hospital Centre Sestre milosrdnice}

In order to improve the management of complaints handling, University Hospital Centre Sestre milosrdnice has modified the complaint handling procedure in 2015. The complaint form has been simplified and written submissions have been made possible by filing complaints electronically. All complaints are collected in a unique place in the Legal Affairs Sector which upon the receipt of the complaint, informs the head of the organizational unit to which or to whose employees the complaint relates.

The patient may file a complaint in several ways:

- In writing, on the official hospital form: "Submission of a complaint/commendation". Complaint forms are available at the hospital department/clinic and on the webpage of the Hospital in the "Patient Guide" section. Complaints or praise can be sent by e-mail.

- Written in the Central Book of Complaints and Commendations that is located at the Information desk in the hospital.
- Electronically through the application: "Electronic Book of Complaints and Commendations", which is on the home page of the University Hospital Centre Sestre milosrdnice website (Figure 1).

Patients can choose the way they are most comfortable with and in order to get an official response to this complaint, the contact address and personal information must be specified. Anonymous and incomplete complaints are also being considered, but they are not answered.

Heads of units are required from The Legal Affairs Sector to investigate the circumstances of the complaint, collect all responses to complaints and, if possible, immediately remove any irregularities. They are also obliged to submit a report to them, in the shortest possible time, facts and actions undertaken, which in cooperation with The Office of Quality is in writing corresponded to the complainant. The Office receives all the complaints, inspects them, carries out their analysis and reports to the Quality and Hospital Administration Commission, whereupon, if necessary, measures are undertaken to improve this area.

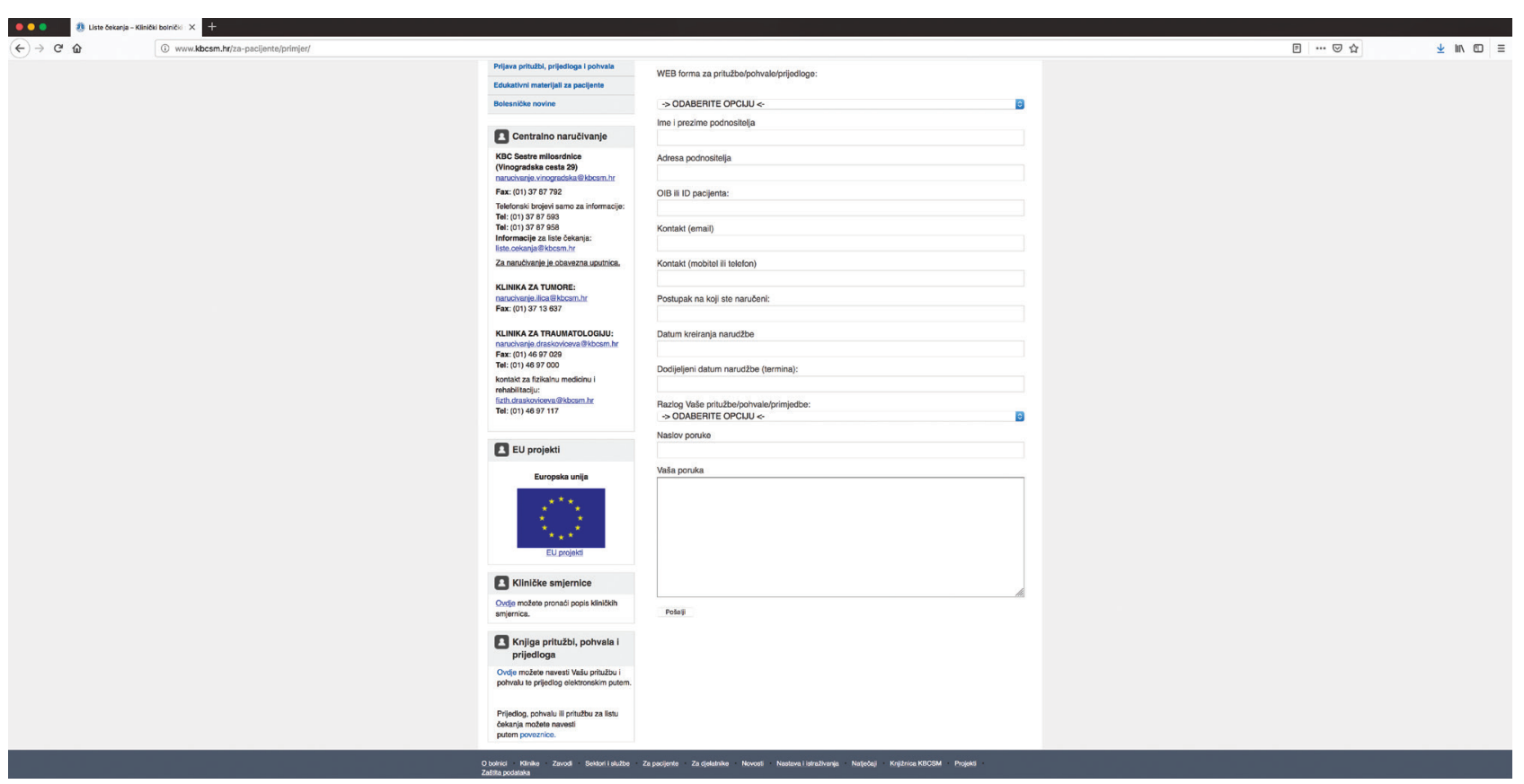

Figure 1. Electronic filing of complaints/commendations at the University Hospital Centre Sestre 


\section{Aim}

The aim of this research was:

1. To analyze all patient complaints in our hospital, with special emphasis on complaints related to the work of nurses.

2. Also, our goal was to analyze complaints in the field of nursing and search answer which category of complaints have differences compared to the others. So hypotheses will be set up:

- Hypotheses 0: There is no difference between the number of complaints for each category.

- Hypotheses 1: There is a difference between the number of complaints for each category.

\section{Methods}

For this research MEDLINE data base was searched and our own classification of complaints was made based on the examples in literature. Distribution of complaints was observed and also testing of hypotheses which referred to the existence of observed and expected differences. Also, patient comments were observed individually.

Data on complaints that was used to do this research was taken from UHC Sestre milosrdnice from the Hospital Register of Complaints.

A document: "Submission of a complaint/commendation", specially designed for filing complaints/commendations in writing or in electronic form is standardized. In this document, a patient may (but not necessarily) enter his/her personal data and contact, date, time and place of his/her complaint, specify the person to whom the complaint/commendation relates as well as the reason for the submission. In the electronic complaint/commendation, the patient can choose the answer offered when he states the place of the event and the reason why he decides in this way to express his or her experiences. In addition, the complainant is offered a blank space where he could describe the subject matter in his/her words.

For the purpose of monitoring and analyzing patient complaints related to the work of nurses, a retrospective analysis of complaints that were part of the Hospital register of complaints in the period from 1st January to 31st December 2017 was made. Despite all the complaints, their frequency and the areas complained of were investigated, special emphasis was placed on the complaints related to the nursing profession. Monitoring and analysis of patient complaints are a common practice of the Office for Quality, which is carried out once a year.

\section{Results}

In the twelve-month period (from 1st January to 31st December 2017) in the UHC Sestre milosrdnice, 142 complaints and 132 commendations were received through the system of collecting complaints/commendations on healthcare workers. From 142 complaints, 21 referred to nurses.

In the analysis of the complaints related to nurses, the areas complained of and the coverage of certain categories of complaints was monitored and also the distribution of complaints regarding nurses' age, sex and working area.

\begin{tabular}{|cc|}
$\begin{array}{c}\text { Table } 1 . \text { Distribution of patient complaints } \\
\text { regarding the nursing work area }\end{array}$ \\
\hline Area & Number and percentage \\
\hline Wards & $5(23 \%)$ \\
\hline Polyclinics & $14(67 \%)$ \\
Intensive Care Units & $1(5 \%)$ \\
Emergency & $1(5 \%)$ \\
TOTAL & $21(100 \%)$
\end{tabular}

In the analysis it was noted that the majority of complaints related to nurses employed in the polyclinic part of the institution. 
Table 2. Distribution of patient complaints regarding category

Category of complaints Number and percentage

Inappropriate
communication

Inappropriate care and

inappropriate behaviour

towards patient

$3(7 \%)$

Violation of patient rights

$10(22 \%)$

Unprofessional behaviour

$14(31 \%)$

TOTAL $45(100 \%)$

Only 21 complaints were addressed to the nurses and some complaints contained several areas where patients complained, so the overall number of complaints was 45 . In the first place, this was inappropriate communication (40\%), but also the unprofessional behavior of the nurses complained of (31\%) and violations of legally prescribed rights of patients (22\%). This complaint classification has been modi- fied in accordance with its own circumstances and based on a classification of complaints that puts them in three leading domains (clinical, managerial, relationships) that continue to fall into different categories and subcategories.

To determine whether there is a statistically significant difference in the share of different categories of patient complaints (Table 2) we have compared them with random distribution. The results show a significant difference $(\chi 2=10.9 ; \mathrm{df}=3 ; p=0.012$ ). We have concluded that the Inappropriate care and Inappropriate behavior toward the patient is statistically significantly lower than the Inappropriate communication $(\chi 2=10.714 ; \mathrm{df}=1 ; p=0.001)$ and Unprofessional behavior ( $\chi 2=7.118 ; \mathrm{df}=1 ; p=0.08$ ).

The analysis shows the distribution of complaints regarding the type of applicant, the manner in which they were filed (given the anonymity and form of submission), as well as the monthly common complaint referred to the nurses. For additional categories of

\begin{tabular}{|c|c|c|c|c|c|}
\hline Month & Applicant & Anonimusly & Sex & Way of complaint & Number of complaints \\
\hline Jan & Accompaniments & No & $\mathrm{F}$ & electronic & 1 \\
\hline Jan & Patient & Yes & $\mathrm{F}$ & electronic & 1 \\
\hline Jan & Accompaniments & No & $\mathrm{F}$ & electronic & 1 \\
\hline Jan & Accompaniments & No & $\mathrm{F}$ & electronic & 1 \\
\hline Jan & Patient & No & $\mathrm{F}$ & electronic & 1 \\
\hline Feb & Accompaniments & No & M & electronic & 1 \\
\hline Feb & Patient & No & $\mathrm{F}$ & electronic & 1 \\
\hline Feb & Patient & Yes & $\mathrm{F}$ & electronic & 1 \\
\hline Feb & Patient & No & $\mathrm{F}$ & electronic & 1 \\
\hline Feb & Patient & No & $\mathrm{F}$ & electronic & 1 \\
\hline Mar & Patient & No & $\mathrm{F}$ & electronic & 1 \\
\hline Mar & Accompaniments & No & $\mathrm{F}$ & electronic & 1 \\
\hline Mar & Accompaniments & No & $\mathrm{F}$ & electronic & 1 \\
\hline May & Patient & No & $\mathrm{F}$ & electronic & 1 \\
\hline Jun & Patient & No & M & electronic & 1 \\
\hline Jul & Accompaniments & No & $F$ & electronic & 1 \\
\hline Sep & Accompaniments & No & $\mathrm{F}$ & electronic & 1 \\
\hline Sep & Patient & No & $\mathrm{F}$ & electronic & 1 \\
\hline Sep & Accompaniments & No & $\mathrm{F}$ & electronic & 1 \\
\hline Oct & Patient & No & M & electronic & 1 \\
\hline Dec & Accompaniments & No & $\mathrm{F}$ & electronic & 1 \\
\hline
\end{tabular}


applications, additional analyses have been made and some statements are specific to each category.

For all of complaints regarding nurses, $48 \%$ pertains to patients and the $52 \%$ pertains to patient's accompaniments. The difference, given who filed a complaint about the work of a nurse (a patient or accompaniments), was not statistically significant: : $\chi^{2}$ $=0.047 ; \mathrm{df}=1 ; \mathrm{p}=0.827$.

Regarding anonymity, 90\% pertains to the complainants without a full name, and the $10 \%$ were not anonymous complainants. The difference given the anonymity of the complaints is statistically significant in relation to the complaints that contained the identification data of the complainant: $\chi^{2}=13.762$; $\mathrm{df}=1 ; p=0.000$ : a significantly smaller number of complaints was filed anonymously.
According to the complainant's sex, $86 \%$ of all complainants are females, and $14 \%$ are males. The difference, given the sex of a person who filed a complaint about the work of nurses, is statistically significant: $\chi^{2}=10.714 ; \mathrm{df}=1 ; p=0.001$ : women significantly more filed complaints.

A patient characterized inappropriate communication towards him by the following example: „Nurse's answer to my question was unprofessional, and in one moment I even saw her rolling her eyes." Inappropriate care and inappropriate behaviour and also violation of patient rights was described by a patient: "Nurse acted very unprofessional and did not provide needed privacy while doing a physical examination."

All complaints were submitted via the internet pages of UHC Sestre milosrdnice.

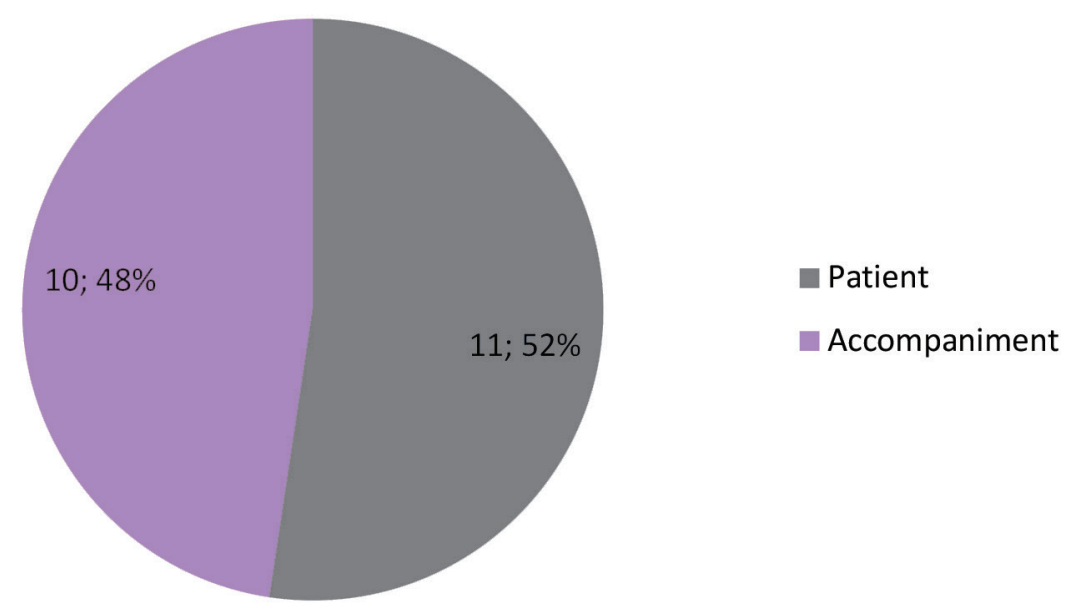

Graph 1. Distribution of complaints by applicant

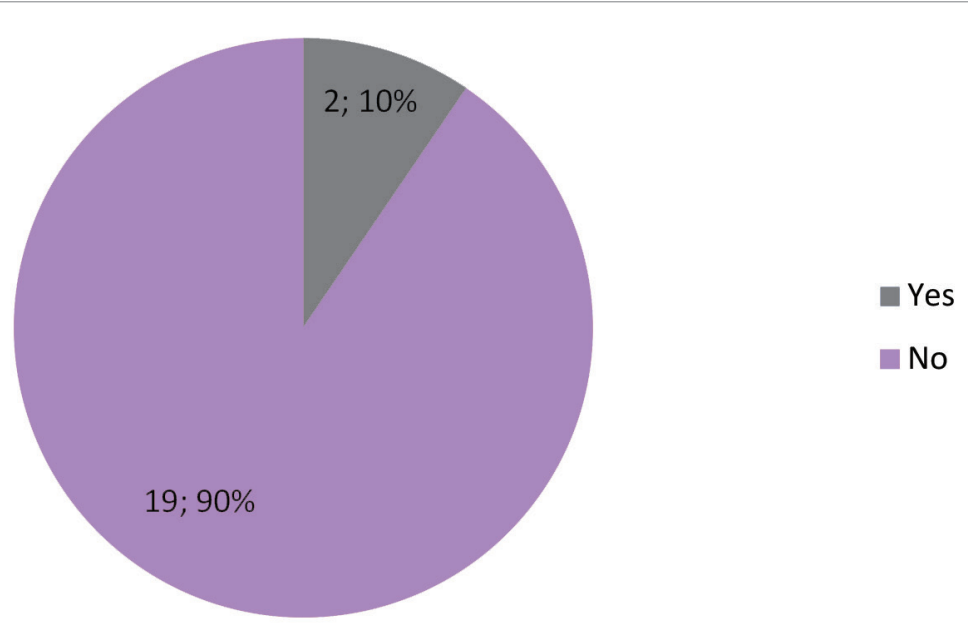




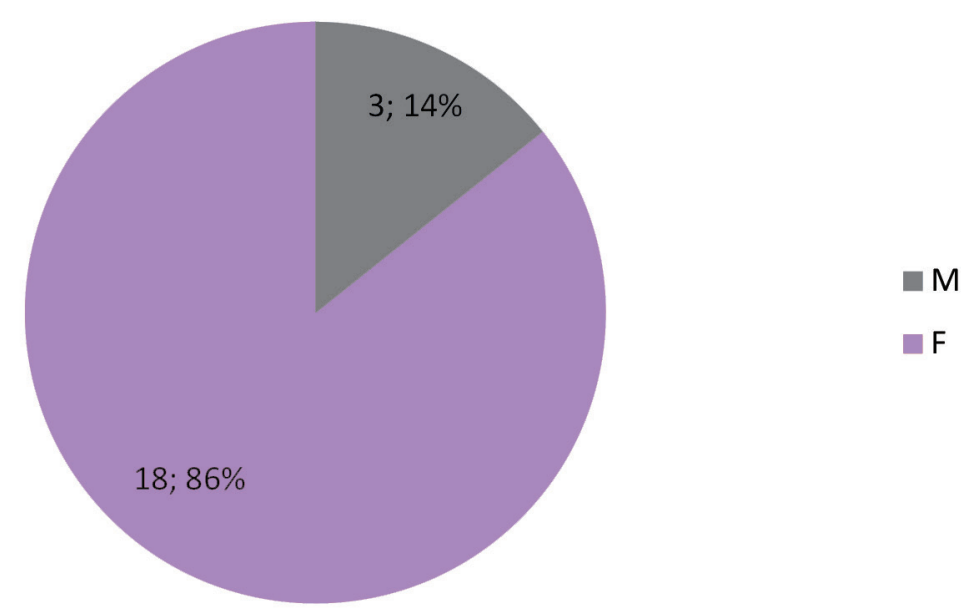

Graph 3. Distribution of complaints regarding complainant's sex

\section{Discussion}

The results of this analysis regarding the frequency of complaints in the field of health care are satisfactory in relation to the frequency of complaints in other research. This percentage is much lower than the percentage of nursing complaints reported in a survey conducted at a regional hospital which was $35.7 \%$ (23). A higher percentage of complaints about nurses was in a research conducted in the United Kingdom. In this study conducted in 24 hospitals, out of 526 complaints, $142(27 \%)$ referred to nurses (17).

The analysis of complaints in this research found that, considering the areas of patient complaints, complaints in the field of communication are frequent in other researches, but differences have been found in relation to research that have been studying complaints in areas where health care is provided (21). Various studies lead to specific conclusions and areas where needed to be improved $(11,17,23,24)$. These differences are precisely the confirmation that patient complaints can identify critical points in the healthcare system of each institution. Most complaints have been referring to nurses who work in polyclinics mostly because there is greatest patient flow rate, sudden events often occur there and patients often wait for a long time to get to the doctor. These situations increase the patient's dissatisfaction and often cause misunderstandings.
Based on the analysis of patient complaints in UHC Sestre milosrdnice, quality improvement activities have already started. Responsible staff have regular meetings with employees where they deal with problems and try to find out what can be done to make patients feel more secure and satisfied with the service they get. Every employee is notified (nurses) when a complaint refers to them. Also, four training cycles have been held: „Communication skills in the daily work of healthcare workers". This training was intended for people who are in close daily contact with the patient (primarily staff who work at polyclinics, which is largely made up of nurses). In addition to the lectures, workshops were held where participants exchanged experiences and gained the opportunity to use an anonymous survey to visualize the problems that arise in the work of staff at polyclinics and outpatient facilities.

Through this research, which included patient health complaints analysis, it was found that apart from communication, it is important to pay attention to the awareness of nurses about the importance of their professional behavior, including the rights of patients. Additionally, a hypothesis that there are differences in the categories of complaints was also been confirmed.

This knowledge is one of the next challenges in improving the quality of nursing care for UHC Sestre milosrdnice.

This research has one disadvantage and it is that it was conducted in only one hospital so we cannot 
generalize it. However, this research is a small step forward to raise awareness of this issue in the nursing profession, as well as the incentive to approach this area more seriously. Data obtained by research is important for all nurses regardless of the field they work in because they play a significant role in ensuring quality health care. By managing the quality of health care, special attention should be paid to patient complaints, to consider the messages received by their analysis, and to use guidelines and recommendations on best practice in this area.

\section{Conclusion}

Patient complaints may point to the various problems that arise in the process of providing health services, especially nursing care. They can describe areas of risk for patient safety, they can be the basis for resolving dissatisfaction, creating areas for changes and preventing future problems. This analysis has provided some insight into complaints about the work of nurses and can point to critical areas in their daily work. In this analysis the most common category has been in the domain of communication, it was found that this area was a priority. Due to the importance and impact of complaints about the quality of nursing care, it is necessary to continuously monitor and analyze them.

This research is a small attempt to raise awareness of the importance of the nursing profession and the role of consideration and analysis of patient complaints in improving the quality of health care.

\section{References}

1. Barlow J, Moller CA. Complaint is a gift: Using Customer Feedback as a Strategic Tool. San Francisco: Berrett Koehler Publishers; 1996.

2. Mulcahy L, Tritter J. Pathways, pyramids and icebergs? Mapping the links between dissatisfaction and complaints.
Sociol Health IIIn. 1998;20:825-47. Available from: https:// www.ncbi.nlm.nih.gov/pmc/articles/PMC3075540/

3. Reader TW, Gillespie A, Roberts J. Patient complaints in healthcare systems: a systematic review and coding taxonomy. BMJ Qual Saf. 2014;23(8):678-89. Available from: http://qualitysafety.bmj.com/content/ early/2014/05/29/bmjqs-2013-002437

4. The Australian Council for Safety and Quality in Health Care. Complaints Management. Handbook for Health Care Services. Australia: Australian council for safety and quality in health care. Available from: https:// wwW.safetyandquality.gov.au/former-publications/ complaints-management-handbook-for-health-careservices-pdf-588-kb/

5. Narodne novine. Zakon o zaštiti prava pacijenata. Zagreb: Narodne novine d.d. 2008. Croatian.

6. Narodne novine. Pravilnik o standardima kvalitete i načinu njihove primjene. Zagreb: Narodne novine d.d. 2011. Croatian.

7. Narodne novine. Pravilnik o akreditacijskim standardima za bolničke zdravstvene ustanove. Zagreb: Narodne novine d.d. 2011. Croatian.

8. Bendall - Lyon D, Powers TL. The role of compliant management in the service recovery process. Jt Comm J Qual Improv. 2001;27(5):278-86.

9. Allen LW, Creer E, Leggitt M. Developing a patient tracking system to improve performance. Jt Comm J Qual Improv. 2000;26(4): 217-26.

10. Department of Health and Social Security: Health service management: Health service complaints procedure. London:DHSS. 1981.

11. Lloyd - Bostock S, Mulcahy L. The Social Psychology of making and responding to hospital complaints: an account model of complaint processes. Law \& Policy 1994;16:123-47.

12. Donaldson L. An organisation with a memory: Learning from adverse events in the NHS. London: Department of Health, 2000.

13. Sorić - Uranić A, Šimunec D. Snaga hrvatskog sestrinstva. Plavi fokus. 2006;2(2):4-10. Croatian.

14. Huber D. Leadership and Nursing Care Management. Second edition. Philadelphia: Saunders; 2000.

15. Narodne novine. Zakon o sestrinstvu. Zagreb: Narodne novine d.d. 2011. Croatian.

16. Patient complaints: Guidance for nurses. Nurs Stand. 1992;7(7):29-30. doi: 10.7748/ns.7.7.29.s41. Available from: https://www.ncbi.nlm.nih.gov/pubmed/1467227

17. Bark P, Vincent $C$, Jones A, Savory J. Clinical complaints: a means of improving quality of care. Qual Health Care. 1994;3(3):123-32.

18. Hsieh SY. An exploratory study of complaints handling and nature. Int J Nurs Pract. 2012;18(5):471-80.

19. Bismark M, Dauer E, Paterson R, Studdert D. Accountability sought by patients following adverse events from medical care: The New Zealand Experience. CMAJ. 2006;175(8):889-94. 
20. Čerfalvi V, Benceković Ž. Pritužbe pacijenata - alat za poboljšanje kvalitete usluge u bolnicama. Poslovna izvrsnost. 2017;XI(1):63-9. Croatian.

21. Taylor DM, Wolfe R, Cameron P. Analysis of complaints lodged by patients attending Victorian hospitals, 1997-2001. Med J Aust. 2004;181(1):31-5.

22. Royal College of Nursing. Patient complaints: guidance for nurses. Nurs Stand. 1992;7(7):29-30. doi:10.7748/ns.7.7.29.s41
23. Jabbari A, Khorasani E, Jafarian Jazi M, Mofid M, Mardani R.The profile of patients' complaints in a regional hospital. Int J Health Policy Manag. 2014;2(3):131-5. Available from: http://www.ijhpm.com/article_2832.html

24. Allsop J, Mulcahy L. Dealing with clinical complaints. Qual Health Care. 1995;4:135-43. Available from: http:// qualitysafety.bmj.com/content/qhc/4/2/135.full.pdf

25. International Committee of Nursing. Toolkit on Complaints Management. 2012. 


\section{Sažetak}

Uvod. Pritužbe pacijenata ukazuju na nezadovoljstvo pacijenata zdravstvenom uslugom (zdravstvenom njegom i sl.). Neadekvatno postupanje s pritužbama pacijenata može rezultirati negativnim posljedicama za ustanove, ali i djelatnike uključene u proces zdravstvene skrbi. Zdravstvene ustanove u Republici Hrvatskoj dužne su propisati postupak upravljanja pritužbama pacijenata, koji mora zadovoljavati određene kriterije. U skladu s tim kriterijima, ustanove mogu uvesti vlastiti način postupanja s pritužbama pacijenata. Postupak uključuje praćenje, analizu i korektivne radnje na temelju analize pritužbi. Medicinske sestre čine veliki broj zaposlenika zdravstvenih ustanova (posebno bolničkih) i njihove usluge znatno pridonose cjelokupnoj kvaliteti njihovih usluga te su važan čimbenik u osiguranju kvalitete i pozitivne percepcije zdravstvene usluge. Stoga je važno upravljati pritužbama i u području zdravstvene njege.

Cilj. Cilj je ovog rada istražiti upravljanje pritužbama u području zdravstvene njege, prikazati način upravljanja pritužbama u KBC-u Sestre milosrdnice, izvršiti analizu pritužbi pacijenata, s posebnim naglaskom na pritužbe koje su se odnosile na rad medicinskih sestara.

Metode. Provedeno je pretraživanje baza podataka u cilju pronalaženja literature iz ovog područja i retrospektivna analiza pritužbi pacijenata podnesenih kroz bolnički sustav prijave pritužbi/pohvala u razdoblju od 1. siječnja do 31. prosinca 2017.
Rezultati. U navedenom razdoblju zaprimljeno je i analizirano 147 pritužbi i 132 pohvale. Od ukupnog broja pritužbi, 21 (14 \%) se odnosila na medicinske sestre. Većina pritužbi (66 \%) odnosila se na medicinske sestre zaposlene u polikliničkoj djelatnosti. Pritužbe su u najvećoj mjeri ukazivale na nezadovoljstvo komunikacijom (40 \%) te, po mišljenju pacijenata, na neprimjeren odnos prema njima (31 \%).

Zaključak. Dobiveni rezultati predstavljaju smjernice za provođenje daljnjih mjera za poboljšanje kvalitete zdravstvene skrbi u ovom području.

Ključne riječi: pritužbe pacijenata, upravljanje, medicinske sestre, kvaliteta 